\title{
The Lamington Conglomerate: further evidence for an ophiolitic source for the Ordovician Marchburn Formation, Northern Belt, Southern Uplands
}

\author{
Hugh F. BARron, Emrys R. Phillips and JAMES D. Floyd \\ British Geological Survey, Murchison House, West Mains Road, Edinburgh, EH9 3LA \\ (e-mail: hfb@bgs.ac.uk)
}

Total Number of words: 3493

Abstract: 137

Figures: 3

Synopsis

Formerly regarded as an outlier of Lower Old Red Sandstone conglomerate within the Northern Belt of the Southern Uplands, the newlydefined Lamington Conglomerate Member is now proposed to be an integral part of the Marchburn Formation (Tappins Group) of Ordovician (Caradoc) age. Pebbles and cobbles (up to $210 \mathrm{~mm}$ in size) are dominated by gabbroic and basaltic lithologies, with subsidiary amounts of tonalite, serpentinite, volcanic breccia and sedimentary lithic clasts. The matrix to the conglomerate is composed of a distinctive pyroxene-bearing sandstone. The member also has unusually high magnetic susceptibility, reminiscent of other units within the Tappins Group further to the southwest, and consistently higher than any Old Red Sandstone conglomerate. The clast content supports an ophiolitic provenance for this part of the Marchburn Formation and is consistent with the overall petrography of the Tappins Group . 


\section{Introduction}

The Lamington Conglomerate Member is a poorly exposed unit of maroon to dark green pebble conglomerate cropping out adjacent to the A702, immediately south of the Southern Upland Fault at Loanhead, near the village of Lamington (Figure 1), South Lanarkshire. Lack of visible contacts, its discordant bedding relationship with the surrounding Marchburn Formation and the absence of known local Ordovician equivalents led the original surveyors (Institute of Geological Sciences 1980) to assume it was the stratigraphical equivalent of the Lamancha Conglomerate (LCHA) of the Siluro-Devonian Lanark Group (Lower Old Red Sandstone). The latter is a poorly indurated rudite of fluviatile aspect with imbricated pebbles, which crops out some $30 \mathrm{~km}$ along strike to the north-east in the Peebles district (Hughes \& Boland 1995; British Geological Survey 1996).

However, re-valuation of the induration and petrography of the matrix (see below), together with the clast content and very high magnetic susceptibility, suggests that the unit is more likely to be a rudaceous facies within the Marchburn Formation (Floyd 1982). We propose that the Lamington Conglomerate Member (LAMN) is an integral part of the Marchburn Formation (MCHB), part of the Tappins Group (TAP).

\section{Geological setting}

The Marchburn Formation, a succession of mainly dark green quartz-poor sandstone turbidites of Caradoc age (Floyd 1996, 2001), occurs adjacent to the Southern Upland Fault at the northern margin of the Northern Belt in the Southern Uplands (Figure 1). It forms part of the Tappins Group, which occupies the oldest fault-bounded clastic tectonostratigraphical tract in the terrane (Figure 2). The Marchburn Formation is dominated by wacke sandstone, but also contains siltstone and mudstone as well as debris flow or slump deposits at or near its base (Smith et al., 2001). A distinctive facies comprising lenticular bodies of microconglomerate is known locally as 'Haggis Rock'. This microconglomerate is characterised by the presence of red, green-grey and black chert and mudstone fragments, but also contains granule to small pebble-sized clasts of basalt, quartz, intermediate to acidic igneous rock (e.g. felsite, microdiorite) and high-grade metasedimentary rocks (indicative of a mixed continental/volcanic source). The microconglomerates are interpreted as mass or debris flow deposits and form thick $(\leq 50 \mathrm{~m})$, graded channel-like units ( $\leq 1 \mathrm{~km}$ wide) with sharp erosive bases. Smith et al., (2001) noted that the proportion of Haggis Rock within the sequence decreases northeast in the Peebles area, probably reflecting a facies change to finer-grained lithologies within the Marchburn Formation .

Although there are spectacular coarse rudite members within the Tappins Group in south-west Scotland such as the Corsewall Point (CPC), Finnarts (FIC) and Glen App (GAPC) conglomerates of the Corsewall Formation (Figure 2 and Kelling 1961, 1962; Phillips \& Floyd 1999; Floyd 1996, 2001; Smith et al., 2001), lithologies containing extra-basinal clasts coarser than c. 5 mm (i.e. Haggis Rock) are rare within the Marchburn Formation, which represents the Tappins Group to the north-east of Loch Bradan [NX 41 97] in the Carrick Forest. The Lamington Conglomerate Member is, therefore, somewhat unusual in having such a coarse clast size, although some conglomerates with large intra-basinal clasts of 
mudstone and wacke sandstone are known from the New Cumnock area to the south-west of Lamington (Floyd 1982). The Lamington Conglomerate may be up to $300 \mathrm{~m}$ thick and crops out as a lenticular mass $1300 \mathrm{~m}$ in length, between [NS 990 312] and [NT 001 321] (Figure 1). At Crow Craigs [NS 991 313], hillside exposures reveal a mostly matrix-supported, poorly-sorted conglomerate with sub-rounded to well rounded clasts up to $210 \mathrm{~mm}$ in diameter in a coarse to very coarse-grained lithic wacke sandstone matrix. The conglomerate, of indeterminate bed thickness, appears to fine toward the north-east; in the Hawmoor Burn [NS 998 318] rounded to well rounded clasts reach a maximum clast size of $30 \mathrm{~mm}$. A lens of purple to dark greenish-grey, coarse to very coarse-grained pebbly lithic wacke sandstone also occurs at a small disused quarry [NS 9916 3122] in Loanheadhill Plantation.

The Lamington Conglomerate Member is also distinguished by its very high magnetic susceptibility, which ranges up to $45.0 \times 10^{-3}$ SI. This is higher than most other conglomerates within the Ordovician sequence of the Northern Belt. Susceptibility values for the adjacent non-conglomeratic Marchburn Formation at Lamington generally range up to $0.49 \times 10^{-3} \mathrm{SI}$, though an isolated exposure of sandstone along strike from the conglomerate has a susceptibility of $3.86 \times 10^{-3}$ SI. Local exposures of Haggis Rock microconglomerate have also been noted (Figure 1) with magnetic susceptibilities as high as $42.5 \times 10^{-3}$ SI. (c.f. Corsewall Point (CPC) 0.3; Glen App (GAPC), 0.6, Carsphairn (CAPH), $0.3 \times 10^{-3}$ SI (Figure 2 and Floyd 1996)). However, these values are comparable with some of the sandstone units such as the purple-red wackes of the Traboyack Formation (TRA), (Floyd \& Kimbell 1995) within the Tappins Group in the area south of Girvan, in south-west Scotland (Figure 2).

\section{Petrography}

A number of samples of the sandstone and microconglomeratic layers, as well as pebble- to cobble-sized lithic clasts were taken from the Lamington Conglomerate Member for detailed petrological analysis.

Sandstones and microconglomerates

The coarse-grained sandstones and microconglomerates interbedded with, and forming the matrix of the Lamington Conglomerate Member are, in general, poorly sorted, closely to very closely packed, immature, clast supported, lithic-rich rocks characterised by the presence of fresh detrital clinopyroxene (Figure 3a). Detrital grains are angular, subangular to occasionally subrounded with a low sphericity and in some rocks the pyroxene is grey to pinky brown Ti-augite, suggesting that the source area included alkaline basaltic igneous rocks. The larger granule to small pebble sized clasts (up to 15 $\mathrm{mm}$ ) are primarily composed of basic igneous rock fragments; including variably metamorphosed gabbro and microgabbro, fine-grained diorite, various fine- to medium-grained basalts, carbonate altered andesite, fine-grained pyroxenite, tonalite with a well developed micrographic intergrowth, volcanic glass, an actinolite-rich rock and serpentinite. Sedimentary lithic clasts composed of pyroxene-rich sandstone are also present, suggesting at least some penecontemporaneous reworking of the Marchburn 
Formation or equivalent lithologies. The metamorphosed gabbroic lithologies exhibit some replacement of primary pyroxene by brown hornblende and later secondary actinolitic amphibole.

Minor to accessory detrital components present within the sandstones include plagioclase, mono- and polycrystalline quartz, carbonate, chlorite, epidote, chloritised rock or pseudomorphs after ferromagnesian minerals, hornblende, opaque minerals and chloritised biotite. Trace amounts of a hematitic/clay, quartz, carbonate and/or a chlorite cement may be present. However, intergranular pressure dissolution forms the main mode of cementation within the sandstone matrix of these microconglomerates. Compaction also led to the modification of the shape of unstable lithic clasts resulting in embayment/moulding against adjacent less soluble grains.

\section{Pebble to cobble sized lithic clasts}

Lithic clasts collected from the Lamington Conglomerate Member are mainly composed of microporphyritic (phenocrysts $\leq 2.0 \mathrm{~mm}$ ) basaltic lavas and variably metamorphosed gabbros and microgabbros. The fine- to very fine-grained basalts comprise plagioclase, clinopyroxene and rare ?orthopyroxene phenocrysts set within a very fine-grained, originally glassy groundmass (Figure 3b). Anhedral to subhedral plagioclase typically occurs as single, isolated phenocrysts. However, glomerophyric clusters of several finer-grained crystals are also present locally. Clinopyroxene phenocrysts are typically smaller than those of plagioclase, with fresh, colourless pyroxene forming anhedral to subhedral, fractured crystals. The originally glassy groundmass is composed of randomly orientated plagioclase, with interstitial to intersertal phases having been replaced by a cryptocrystalline assemblage of chlorite, granular epidote and opaque oxides.

The gabbros and metagabbros are, in general, medium- to coarse-grained, massive, holocrystalline rocks that consist of an inequigranular assemblage of plagioclase, clinopyroxene and amphibole with minor to trace amounts of opaque minerals and titanite (Figures $3 c$ and d). Although metamorphosed, the original igneous texture of the gabbros is still recognisable, consisting of a framework of equant to prismatic, anhedral, variably sericitised plagioclase crystals (up to c. $2.0 \mathrm{~mm}$ ) with intergranular ophitic clinopyroxene. Pyroxene has been variably altered to, or pseudomorphed by brown-green to green hornblende with the latter exhibiting minor secondary replacement by actinolite. Anhedral to irregular, relict clinopyroxene occurs within the cores of the larger hornblende crystals. Mesh-textured chlorite pseudomorphs after possible olivine were noted within the apparently more melanocratic rocks. In the most intensely metamorphosed lithologies the primary mineral assemblage has been completely replaced by actinolitic amphibole, hornblende, chlorite and saussuritised plagioclase.

A small number of lithic clasts within the conglomerate are composed of a quartz-bearing, tholeiitic microgabbro. This consists of a framework of randomly orientated plagioclase laths with intergranular clinopyroxene, minor orthopyroxene and opaque minerals. The remaining interstitial phases are typically replaced by very fine-grained chlorite, along with possible prehnite or pumpellyite. 
Rare clasts of a medium-grained, ophimottled basalt, amphibole-feldspar microporphyritic andesite or dacite, variably altered amygdaloidal basalt and coarse volcanic breccia were also noted from the Lamington Conglomerate. The basalt is composed of small $(\leq 0.4 \mathrm{~mm})$, randomly orientated plagioclase laths included within large, (0.5 to $1.5 \mathrm{~mm}$ ) intergranular, ophitic clinopyroxene crystals. The coarse volcanic breccia comprises large, irregular to angular lithic clasts of plagioclase-clinopyroxene microporphyritic basalt, medium- to coarse-grained, amygdaloidal basalt and rare clasts of an amphiboleplagioclase microporphyritic andesite.

\section{Discussion: origin and provenance of the Lamington Conglomerate Member}

Many of the thickly bedded, turbiditic sandstones that dominate the Marchburn Formation are rich in detrital clinopyroxene (Styles et al., 1995), magnetite, and fragments of metabasalt, gabbro and serpentinite. Petrological (see Floyd 1996; Smith et al., 2001), geochemical (Duller \& Floyd 1995) and isotopic studies (Evans et al., 1991; Stone \& Evans 1995) indicate that this extra-basinal material represents juvenile ophiolitic detritus that was introduced into both the Marchburn and Corsewall formations. Conglomerates in the latter formation have a more varied clast composition including granite, rhyolite, andesite, gabbro and diorite (Smith et al., 2001). Sedimentological evidence (c.f. Walker 1978) indicates that the Marchburn Formation was deposited in a proximal, sand-rich submarine fan environment, with the microconglomerates ('Haggis Rock') representing channel-fills and the finergrained mudstones and siltstones, overbank deposits. In the Leadhills area, Smith et al. (2001) noted that the Marchburn Formation records an overall fining-upwards succession and concluded that this was consistent with either a switching of the feeder channels, resulting in fan-lobe abandonment, or that the basin was becoming starved of coarse clastic detritus. However, in the Lamington area, Haggis Rock microconglomerate continued to be deposited in the youngest part of the Marchburn Formation, supporting the channel switching model. Sparse palaeocurrent evidence from the Marchburn Formation suggests derivation mainly from the north-east or north-west and is, therefore, thought to record both axial and transverse transport directions within the NE-SW-trending Southern Uplands basin.

The predominance of gabbroic and basaltic rock fragments within the Lamington Conglomerate Member indicates that it was probably derived from the same juvenile ophiolitic source as the remainder of the Marchburn Formation. The presence of fresh detrital clinopyroxene within both the sandstones of the Marchburn Formation and matrix of the Lamington Conglomerate clearly indicates that this basic igneous detritus was undergoing limited transport within the sedimentary environment. The massive, weakly bedded nature of the Lamington Conglomerate suggests that it is a mass or debris flow deposit, possibly filling a major channel feeding fresh coarse-grained basic igneous debris deeper into the Southern Uplands basin. The presence of this and other channelised mass flow deposits within the sandrich turbidite fan system of the Marchburn Formation suggests that this basin was tectonically active.

Small volumes of basaltic pillow lava, associated with volcanic breccia and red-green chert, occur interbedded with the sandstones of the Marchburn Formation, for example, the $c .100 \mathrm{~m}$ thick 
Noblehouse Lava Member (NBL) exposed in the Leadburn area (Figure 2). These alkaline and tholeiitic basalts display geochemical characteristics of lavas erupted in a within-plate oceanic setting (Phillips et al., 1995). It is possible that they provided an intra-basinal source for at least some of the basic igneous material present within the Lamington Conglomerate and Marchburn Formation.

The range of gabbroic and basaltic rocks present within the Lamington Conglomerate Member is petrographically similar to that within the Ballantrae ophiolitic complex exposed to the southwest within the adjacent Midland Valley Terrane. The Southern Uplands and Midland Valley terranes are separated by a major strike-slip fault, the Southern Upland Fault (Floyd 1994). Estimates of the amount of displacement along the fault range from no more than a few hundred $\mathrm{km}$ (and possibly much less - Owen and Clarkson 1992) up to c. $1500 \mathrm{~km}$ (e.g. Elders 1987). Some of the basaltic lavas within the Ballantrae complex contain unaltered clinopyroxene phenocrysts, with the associated gabbroic and microgabbroic rocks displaying a similar style of alteration/metamorphism to that of the gabbro lithic clasts in the Lamington Conglomerate; namely saussuritised plagioclase and replacement of clinopyroxene by brown amphibole and later secondary actinolitic amphibole (Jelinek et al., 1984). The early Ordovician Ballantrae Complex is believed to have been formed in an oceanic supra-subduction zone setting and obducted onto the Midland Valley Terrane during the Arenig (see Stone \& Smellie 1990 and references therein). Comparable, ophiolitic fragments occur within the lateral extension of the Midland Valley Terrane in Ireland; for example the Tyrone Igneous Complex (County Tyrone) that includes a gabbrodolerite-pillow basalt ophiolitic assemblage obducted during the Arenig to Llanvirn (c. $472 \mathrm{Ma}$, Hutton et al., 1985). Smith et al. (2001) noted that the onset of arenaceous clastic deposition within the Southern Uplands basin, represented by the Tappins Group, broadly corresponds to the beginning of uplift and erosion of earlier obducted ophiolite terranes in Ireland, and possibly also Scotland.

The Lamington Conglomerate Member may, therefore, be interpreted as a mass flow deposit derived from an obducted fragment of oceanic crust. This juvenile ophiolitic terrane also acted as an important source of detritus for the Marchburn Formation sequence during the early phase of clastic deposition within the Southern Uplands basin. The presence of such ophiolitic material within the now adjacent Midland Valley Terrane has important implications for terrane reconstructions in the region, in particular, possibly limiting the scale of displacement along the boundary separating the Midland Valley and Southern Uplands terranes (c.f. Owen and Clarkson 1992).

\section{Conclusions}

The Lamington Conglomerate, formerly considered to be of Old Red Sandstone conglomerate facies, is now interpreted as an unusual rudite member within the Marchburn Formation of the Ordovician Leadhills Supergroup in the Northern Belt of the Southern Uplands. The conglomerate contains extrabasinal lithic clasts, which are dominantly of fresh plagioclase-clinopyroxene-phyric basalts and variably metamorphosed gabbroic rocks. The interbedded sandstones and microconglomerates, together with the matrix to the Lamington Conglomerate, all contain fresh detrital clinopyroxene 
indicating a very short period of transport within the sedimentary environment. Clast composition and magnetic susceptibility values are consistent with the overall petrographic properties of the Tappins Group and support an ophiolitic provenance for this part of the Southern Uplands sedimentary sequence.

\section{Acknowledgements}

This work forms part of the Southern Scotland and Northern England Integrated Surveys Project currently being undertaken by the British Geological Survey. Brian Bluck and Alan Owen are acknowledged for their constructive comments on earlier versions of this paper. This paper is published with the permission of the Director, British Geological Survey, (NERC). 


\section{References}

BRITISH GEOLOGICAL SURVEY. 1996. Peebles. Scotland Sheet 24E. Solid Geology. 1:50 000. British Geological Survey, Keyworth, Nottingham.

DULLER, P. R. and FLOYD, J. D. 1995. Turbidite geochemistry and provenance studies in the Southern Uplands of Scotland. Geological Magazine, 132, 557-569.

ELDERS, C. F. 1987. The provenance of granite boulders in conglomerates of the Northern and Central Belts of the southern Uplands of Scotland. Journal of the Geological Society, London, 144, 853-863.

EVANS, J. A., STONE, P. and FLOYD, J. D. 1991. Isotopic characteristics of Ordovician greywacke provenance in the Southern Uplands of Scotland. In: MORTON, A. C., TODD, S. P. and HAUGHTON, P. D. W. (eds.). Developments in Sedimentary Provenance Studies. Geological Society of London, Special Publication, 57, 161-172.

FLOYD, J. D. 1982. Stratigraphy of a flysch succession: the Ordovician of W Nithsdale, SW Scotland. Transactions of the Royal Society of Edinburgh: Earth Sciences, 73, 1-9.

FLOYD, J. D. 1994. The derivation and definition of the 'Southern Upland Fault': a review of the Midland Valley - Southern Uplands terrane boundary. Scottish Journal of Geology, 30, 51-62.

FLOYD, J. D. 1996. Lithostratigraphy of the Ordovician rocks in the Southern Uplands: Crawford Group, Moffat Shale Group, Leadhills Supergroup. Transactions of the Royal Society of Edinburgh: Earth Sciences, 86, 153-165.

FLOYD, J. D. 2001. The Southern Uplands Terrane: a stratigraphical review. Transactions of the Royal Society of Edinburgh: Earth Sciences, 91, 349-362.

FLOYD, J. D. and KIMBELL, G. S. 1995. Magnetic and tectonostratigraphic correlation at a terrane boundary: the Tappins Group of the Southern Uplands. Geological Magazine, 132, 515-521.

HUGHES, R. and BOLAND, M. 1995. The Ordovician and Silurian rocks of Scottish Sheet 24E (Peebles). British Geological Survey, Technical Report, WA/95/14.

HUTTON, D. H. W., AFTALION, M. and HALLIDAY, A. N. 1985. An Ordovician ophiolite in County Tyrone, Ireland, Nature 315, 210-212. 
INSTITUTE OF GEOLOGICAL SCIENCES. 1980. Biggar. Scotland Sheet 24W. Solid Geology. 1:50 000. Institute of Geological Sciences, Edinburgh.

JELINEK, E., SOUCEK, J., RANDA, Z., JAKES, P., BLUCK, B. J. and BOWES, D. R. 1984. Geochemistry of peridotites, gabbros and trondhjemites of the Ballantrae Complex, SW Scotland. Transactions of the Royal Society of Edinburgh: Earth Sciences, 75, 211-224.

KELLING, G. 1961. The stratigraphy and structure of the Ordovician rocks of the Rhinns of Galloway. Quarterly Journal of the Geological Society of London, 117, 37-75.

KELLING, G. 1962. The petrology and sedimentation of Upper Ordovician rocks in the Rhins of Galloway, south-west Scotland. Transactions of the Royal Society of Edinburgh, 65, 107-137.

OWEN, A.W. and CLARKSON, E.N.K. 1992. Trilobites from Kilbucho and Wallace's Cast and the location of the Northern Belt of the Southern Uplands during the late Ordovician. Scottish Journal of Geology, 28, 3-17.

PHILLIPS, E. R., BARNES, R. P., MERRIMAN, R. J. and FLOYD, J. D. 1995. The tectonic significance of Ordovician basaltic rocks in the Southern Uplands, SW Scotland. Geological Magazine, 132, 549-556.

PHILLIPS, E. R. and FLOYD, J. D. 1999. The mineralogy, petrology and provenance of lithic clasts from Ordovician and Silurian conglomerates from the Southern Uplands of Scotland. British Geological Survey, Technical Report, WG/99/5.

SMITH, R. A., PHILliPS, E. R., FlOYD, J. D., BARRON, H. F. and PICKETT, E. A. 2001. The Northern Belt 100 years on: a revised model for the Ordovician tracts near Leadhills, Scotland. Transactions of the Royal Society of Edinburgh: Earth Sciences, 91, 421-434.

STONE, P. and EVANS, J. A. 1995. Nd-isotope study of provenance patterns across the Iapetus Suture. Geological Magazine, 132, 571-580.

STONE, P. and SMELLIE, J. L. 1990. The Ballantrae ophiolite, Scotland: an Ordovician island arc marginal basin assemblage. In Malpas, J., Moores, E.M. PAnAyiotou, A. and Xenophontos, C. (eds) Ophiolites: oceanic crustal analogues, 535-46. Geological Survey Department, Nicosia, Cyprus.

STYLES, M. T., PEREZ-ALVEREZ, M. and FLOYD, J. D. 1995. Pyroxenous greywackes in the Southern Uplands of Scotland and their petrotectonic implications. Geological Magazine, 132, 539-547. 
Barron, Phillips \& Floyd. The Lamington Conglomerate

WALKER, R. G. 1978. Deep Water Sandstone Facies and Ancient Submarine Fans: Models for Exploration for Stratigraphic Traps. The American Association of Petroleum Geologists Bulletin, 62, 932966.

MS. Accepted for publication 20 June 2003 


\section{Figures}

Figure 1. Outline geology of the Lamington area. Geological units: BGRV, Biggar Volcanic Formation; MCHB, Marchburn Formation; KKF, Kirkcolm Formation; LAMN, Lamington Conglomerate Member. Inset map shows location of Lamington area.

Figure 2. Tectonostratigraphy of the northern part of the Northern Belt, Southern Uplands Terrane, showing lithostratigraphy within each fault-bounded tract. Units: CAPH, Carsphairn Conglomerate Member; CLG, Corsewall Formation; CPC, Corsewall Point Conglomerate Member; FIC, Finnarts Conglomerate Member; GAPC, Glen App Conglomerate Member; GBS, Glenkiln Shale Formation; KKF, Kirkcolm Formation; KRK, Kirkton Formation; LAMN, Lamington Member; MCHB, Marchburn Formation; NBL, Noblehouse Member; TRA, Traboyack Formation. Based on Floyd 1996 Fig. 2; Floyd 2001

Figure 3. Photomicrographs: (a) coarse-grained, lithic-rich sandstone containing fresh detrital clinopyroxene (sample N2035); (b) fine-grained plagioclase-clinopyroxene microporphyritic basalt (sample N2033); (c) metagabbro containing colourless clinopyroxene and sassuratised plagioclase (N2044); and (d) metagabbro containing intergranular, poikilitic brown hornblende (sample N2029). All photographs taken under plane polarised light. Photographs $5.0 \mathrm{~mm}$ in length (long axis). 


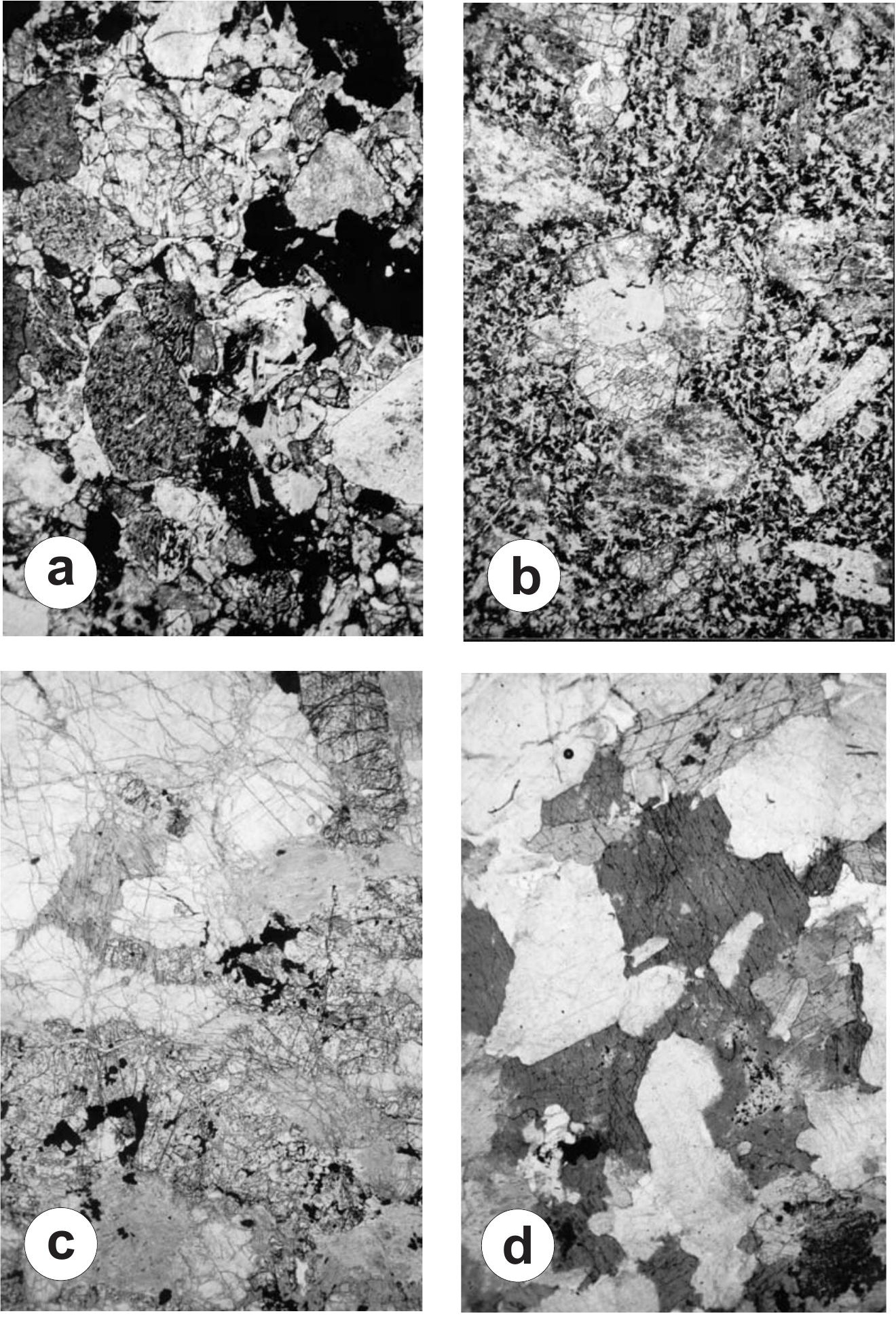

Barron, Phillips \& Floyd Figure 3 



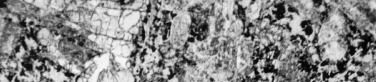

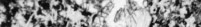

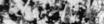
ofest , $3=13$ - $-1,35$

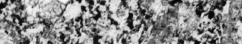
1.

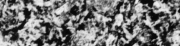

yothe.

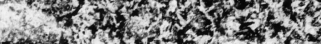

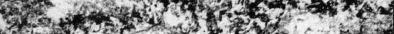

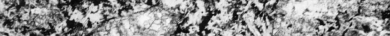

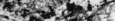

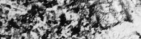

wis.

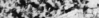

isions?

$20,2 \times 36$

Pons

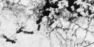

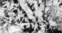

(1) है।

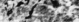

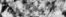

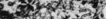

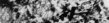

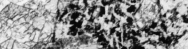

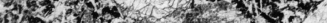

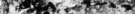

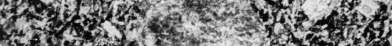

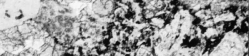

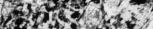
$+4$

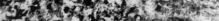

\section{W.}

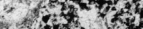

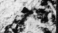

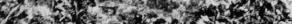

(6)

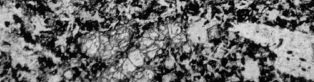

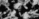
S. s.t. (2)

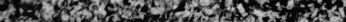

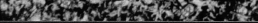





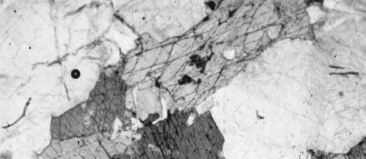

